\title{
THE IMPACT OF COVID-19 EXPANSION ON THE ECONOMY OF COUNTRIES AND ACTIVITIES OF SMALL BUSINESS ENTERPRISES
}

\author{
Tetyana Gogol'1, Vadym Kolotok ${ }^{2}$
}

\begin{abstract}
The purpose of this research is to study the functioning of small business during the period of implementation of quarantine restrictions. It was found out that more than $70 \%$ of small business entities in Ukraine and the European Union have suffered significant losses due to the measures taken. The article has identified the key issues faced by small business during the quarantine period to reduce the spread of coronavirus pandemic (COVID-19). A comparison of the problems of Ukrainian and European small business has shown that they are identical. The main ones relate to reducing the financial security of small business entities and increasing their vulnerability to unpredictable situations. The authors of the research have focused on the fact that Ukrainian small agricultural enterprises experienced more negative effects in comparison with others, as the closure of food markets deprived them of the opportunity to sell their own products. The authors have also highlighted the problems that arise in the process of transition of small business to remote work. This issue can be addressed through appropriate employee training. In order to prevent the loss of ties with contractors, the authors of the research have suggested that the management staff of small business entities could develop a plan to restore ties with suppliers and customers to gradually normalize the workin pre-crisis volumes. The current Ukrainian and European regulatory framework adopted in order to overcome the negative impact of the imposed quarantine restrictions on the activities of enterprises has been analyzed. The results of the study showed the need to improve Ukrainian legislation on this issue taking into account the experience of European countries. It was found out that different countries have applied customs, credit, social, tax, information and other types of mitigation measures in order to overcome the negative effects and to support small business affected by the spread of coronavirus disease (COVID-19). In order to improve the economic situation of small business entities, the authors of the research have considered the following measures for the quarantine period and after the restrictions expire: to provide a quota for public procurement for small business; not to prohibit the functioning of markets provided that they comply with anti-epidemic sanitary norms; reimbursement of expenses incurred for the purchase of anti-epidemic means of protection; introduce additional subventions from the state to local budgets; compensation for the cost of renting premises, etc.
\end{abstract}

Key words: small business, pandemic, quarantine restrictions, financial support, economic problems.

JEL Classification: A10

\section{Introduction}

The spread of coronavirus has become a new challenge for humanity in the 21 st century. In one year, the life of every person has changed dramatically. This pandemic has shown the inability of the world community to respond quickly and efficiently to global threats, forcing humanity to seek new approaches in order to meet challenges of the planet.

Due to the introduced quarantine measures we can observe negative systemic phenomena in the economies of different countries, such as violation of cross-border cooperation, falling world financial markets, record collapse of

\footnotetext{
Corresponding author:

${ }^{1}$ Chernihiv Polytechnic National University, Ukraine.

E-mail: tatyanagogoll@gmail.com

ORCID: https://orcid.org/0000-0002-0885-6271

ResearcherID: F-6030-2016

${ }^{2}$ Chernihiv Polytechnic National University, Ukraine.

E-mail: kolotokvo@ukr.net

ORCID: https://orcid.org/0000-0002-1577-4944

ResearcherID: V-3184-2018
} 
oil prices, devaluation of national currencies, rising unemployment rate, closure of cultural institutions etc. But for the pharmaceuticals, enterprises in all sectors of the economy suffer significant losses. While facing the outflow of migrant workers the business of European countries needs to replace their work.

Small business has suffered the most during the lockdown. Trade and catering services as well as accommodation and travel agencies have been severely restricted. All this affects the activities of small business enterprises negatively, creating a number of additional problems, and inhibits the prospects for their further development. Therefore, they need to implement effective measures to support them by state and local authorities.

Having analyzed various scientific publications on the impact of coronavirus on small business activities, in particular such scientists as Shatalova L. M., Storozhuk T. M., Marynenko N. Yu., Kasperovych Yu. and others, regarding the importance and necessity of economic growth of enterprises during the coronavirus, we have concluded that this issue requires further analysis and research.

The purpose of the research is to study the functioning of small business during the period of implementation of quarantine restrictions.

The objectives of the research are as follows:

- to analyze the problems of small business during the coronavirus pandemic;

- to analyze the implemented measures in order to support small business during the quarantine period;

- make proposals to improve the state support for small business in Ukraine during the pandemic.

\section{Analysis of the problems of small business during the coronavirus pandemic}

The coronavirus pandemic has forced Ukrainian government to introduce quarantine measures. Imposed restrictions deprived small business enterprises of the opportunity to operate normally or even led to the termination of their activities. According to an express survey conducted by European Business Association among the representatives of small and micro business participants in the Unlimit Ukraine project, 18\% of respondents are considering closing their own business, $78 \%$ of respondents report losses of up to $75 \%$ of their revenues and only $4 \%$ of them can boast of increased profits ( $\ll$ Kozhen piatyi malyi biznes... », 2020). Similar situation is observed in the European Union.

McKinsey survey conducted in August 2020 among more than 2,200 small and mediumsized enterprises in five European countries, namely France, Germany, Italy, Spain and the United Kingdom, showed the negative impact of COVID-19 on their economies. About 70\% of respondents said their incomes had declined as a result of the pandemic, having other serious consequences as well. The survey showed that Italian and Spanish small and medium-sized enterprises suffered the most (Figure 1) (Dimson, Mladenov, Sharma, Tadjeddine, 2020).

In other words, due to the spread of coronavirus small business enterprises in Ukraine and the EU have experienced new problems that need an urgent solution. Now we are going to define these problems.

For small business entities that were forced to suspend their activities due to quarantine, the probability of non-repayment of accounts payable increased, as the inflow of financial resources needed to cover fixed and variable costs (rent, wages, communications, internet, etc.) decreased many times. Business entities that continued their operation during the imposed restrictions were forced to find additional sources of funding for the purchase of anti-epidemic means of protection (antiseptics, personal protective equipment, noncontact thermometers, etc.). Management of small and micro business, in order to prevent the onset of insolvency crisis or bankruptcy of the enterprise, began to actively search for the ways to optimize costs, in particular, laying off the employees.

Small farms were particularly affected by restrictions as a result of the closure of food markets, which had no alternative outlets (such as large supermarkets) and deprived them of the opportunity to sell their own products. In modern Ukrainian realities the need for the functioning of markets should be taken into account by the government when imposing restrictions.

Restrictive measures for small business entities have posed a potential threat of loss to previously cooperating consumers and suppliers. Once the quarantine measures are completed, it will be more difficult to restore the normal functioning of small business. The management of small business enterprises needs to develop a plan to re-establish their ties with counterparties in order to gradually normalize the work in pre-crisis volumes. 


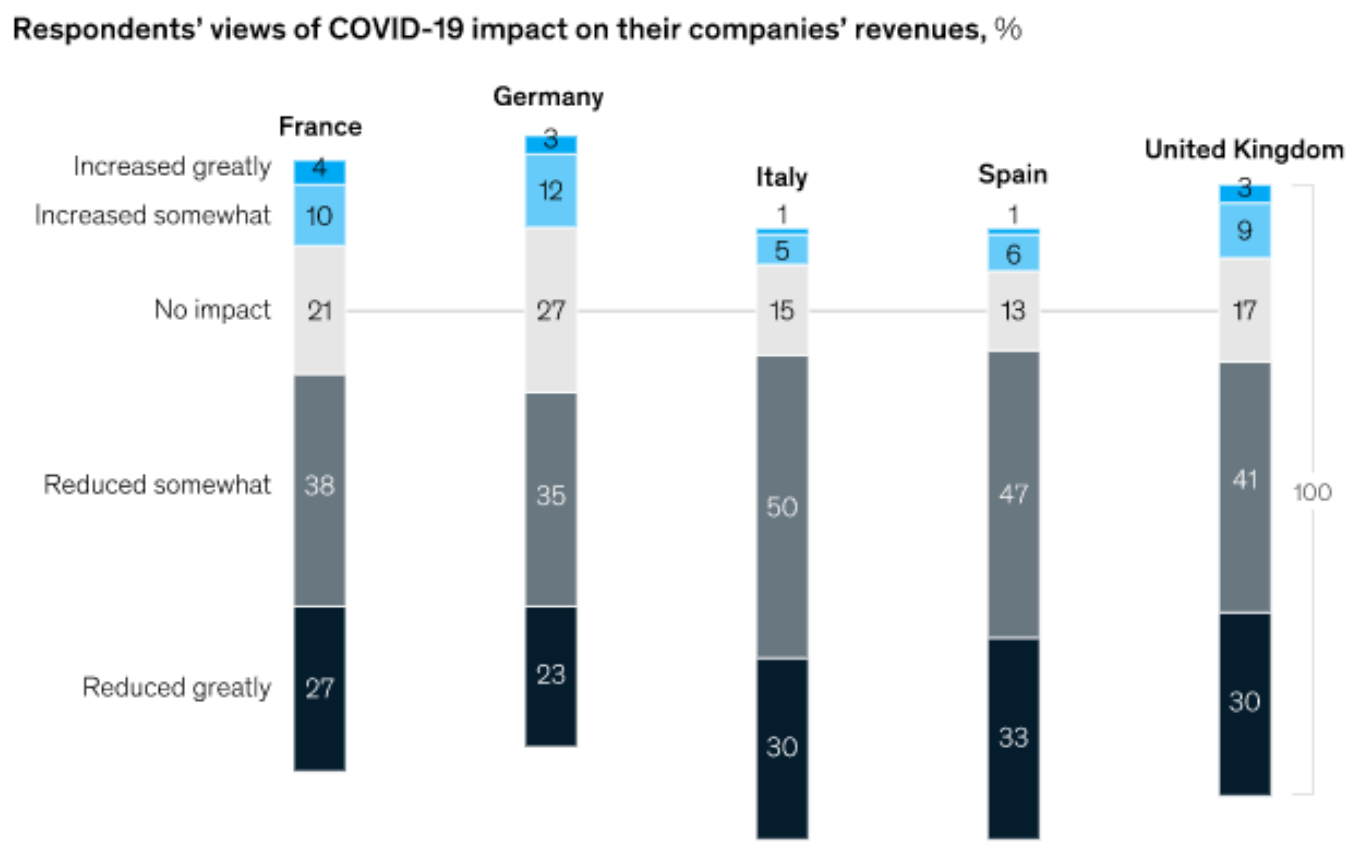

Note: Figures may not sum to 100\%, because of rounding.
Source: Survey of SMEs conducted in August 2020; $n=500$ in United Kingdom, $n=505$ in Germany, $n=502$ in France, $n=351$ in Italy, and $n=350$ in Spain

Figure 1. The impact of coronavirus crisis on small business income

Source: (Dimson, Mladenov, Sharma, Tadjeddine, 2020)

Transition to remote work does not allow small business to shut down during the pandemic, but the interaction between employees may deteriorate due to a number of factors:

- lack of knowledge and skills of employees for the effective use of information technology;

- lack of reliable Internet coverage at the place of remote work;

- inability to install software required by the employee to perform the assigned functions properly.

\section{Analysis of developed and implemented measures to support small business during the coronavirus pandemic}

One of the problems arising at the beginning of the quarantine was lack of regulations for remote work. Due to the need for legislative regulation of issues related to remote (home) work (wages, distribution of working time, etc.) the provisions of the Labour Code were changed ( $\ll$ Kodeks zakoniv pro pratsiu Ukrainy», 1971), by adopting the Law of Ukraine "On Amendments to Certain Legislative Acts of Ukraine Aimed at Providing Additional Social and Economic Guarantees in Connection with the Spread of Coronavirus Disease (COVID-19)" of 30.03.2020 ( $\ll$ Pro vnesennia zmin ... », 2020). The Code stipulates that employees are paid by the employer for their work to the same extent as it was specified in the employment contract, unless they have agreed to other conditions in writing.

According to the Labour Code at the time of threat of epidemic, pandemic and/or military, man-made, natural or other nature, the condition of remote (home) work and flexible working hours may be established in the order (disposal) of the owner or authorized body without the obligatory conclusion of an employment contract for remote (home) work in writing. At remote (home) work, employees distribute working time at their discretion, thus they are not subject to the rules of internal labour regulations, unless otherwise provided in the employment contract. In this case, the total working time may not exceed the established norms («Kodeks zakoniv pro pratsiu Ukrainy», 1971).

EU bodies and institutions have approved a number of regulations aimed at improving the situation of small business entities during quarantine restrictions and their resumption. We are going to consider some of them (Table 1).

Comparing Ukrainian ( $\ll$ Pro vnesennia zmin do...», 2020; «Podatkovyi kodeks Ukrainy», 
Table 1

EU Regulations to resolve issues related to the spread of the coronavirus pandemic

\begin{tabular}{|c|c|c|}
\hline \multicolumn{2}{|r|}{ Name of regulation } & Review \\
\hline \multirow{2}{*}{ 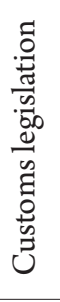 } & $\begin{array}{l}\text { EU Commission Decision 2020/491 of April 03, } 2020 \text { on the } \\
\text { exemptions of import duties and VAT on goods needed to combat the } \\
\text { effects of the COVID-19 epidemic in } 2020 \text {. }\end{array}$ & $\begin{array}{l}\text { The decision exempts the goods needed to } \\
\text { combat the effects of the epidemic COVID-19 } \\
\text { from customs duties and VAT. }\end{array}$ \\
\hline & $\begin{array}{l}\text { Commission's Notification on the implementation of preferential } \\
\text { passages in the context of guidelines on border management measures } \\
\text { to protect health and ensure the availability of basic goods and } \\
\text { services. }\end{array}$ & $\begin{array}{l}\text { The Notification instructs the Member } \\
\text { States to take measures in order to ensure the } \\
\text { uninterrupted transport of goods throughout } \\
\text { the trans-European transport network. }\end{array}$ \\
\hline \multirow{2}{*}{ 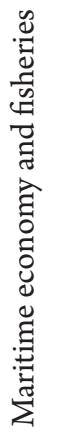 } & $\begin{array}{l}\text { Regulation (EU) } 2020 / 560 \text { of the European Parliament and Council } \\
\text { of April 23, } 2020 \text { on amending the Regulations (EU) No 508/2014 } \\
\text { and (EU) No } 1379 / 2013 \text { as for specific measures to mitigate the } \\
\text { effects of COVID-19 epidemic on the fisheries and aquaculture sector. }\end{array}$ & \multirow{2}{*}{$\begin{array}{l}\text { Regulated measures carried out by the EU to } \\
\text { mitigate the effects of COVID-19 epidemic on } \\
\text { the fisheries and aquaculture sector. }\end{array}$} \\
\hline & $\begin{array}{l}\text { Commission Implementing Regulation (EU) } 2020 / 1027 \text { of July } \\
14,2020 \text { amending Implementing Regulation (EU) No } 771 / 2014 \text {, } \\
\text { (EU) No } 1242 / 2014 \text { and (EU) No } 1243 / 2014 \text { regarding the } \\
\text { implementation and monitoring of specific measures mitigation of } \\
\text { COVID-19 pandemic in the fisheries and aquaculture sector. }\end{array}$ & \\
\hline 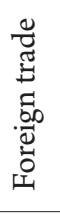 & $\begin{array}{l}\text { Commission's Notification: Guidance to Member States on } \\
\text { Commission Implementing Regulation (EU) 2020/402, providing } \\
\text { the export of certain products subject to the issue of an export } \\
\text { license, as amended by Commission Implementing Regulation (EU) } \\
2020 / 4262020 / C \text { I I/02. }\end{array}$ & $\begin{array}{l}\text { Introduction of an export license for anti- } \\
\text { epidemic goods (personal protective } \\
\text { equipment). }\end{array}$ \\
\hline \multirow{2}{*}{ 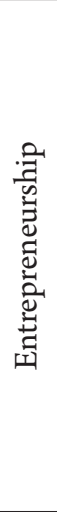 } & $\begin{array}{l}\text { Temporary framework for the Commission's notification of state } \\
\text { aid measures to support the economy in the context of the ongoing } \\
\text { outbreak of COVID-19 2020/C 91 I/01 \{with amendments and } \\
\text { additions\} }\end{array}$ & $\begin{array}{l}\text { Measures for the state support for enterprises } \\
\text { in the following form: direct grants; advance } \\
\text { payments or tax benefits; loan guarantees; } \\
\text { subsidized interest rates on loans; guarantees } \\
\text { and loans provided through credit institutions } \\
\text { or other financial institutions. Short-term } \\
\text { export credit insurance is also provided. }\end{array}$ \\
\hline & $\begin{array}{l}\text { Communication of the Commission } \\
\text { New industrial strategy for Europe }\end{array}$ & $\begin{array}{l}\text { A new EU pharmaceutical strategy is expected } \\
\text { to be presented in response to the spread of } \\
\text { coronavirus disease, focused on the availability, } \\
\text { affordability, sustainability and security of } \\
\text { supply of medicines. }\end{array}$ \\
\hline \multirow{3}{*}{ 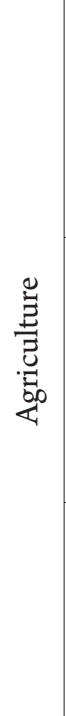 } & $\begin{array}{l}\text { Regulation (EU) } 2020 / 872 \text { of the European Parliament and } \\
\text { Council of June 24, } 2020 \text { amending the Regulation (EU) No } \\
1305 / 2013 \text { regarding specific actions for the provision of exceptional } \\
\text { temporary support under the European Agricultural Fund for Rural } \\
\text { Development (EAFRD) in response to the COVID-19 epidemic. }\end{array}$ & $\begin{array}{l}\text { Support is provided for farmers and SMEs, } \\
\text { especially those affected by the crisis } \\
\text { of COVID-19. }\end{array}$ \\
\hline & $\begin{array}{l}\text { Commission Implementing Regulation (EU) 2020/600 of April 30, } \\
2020 \text { derogating from Implementing Regulation (EU) 2017/892, } \\
\text { Implementing Regulation (EU) 2016/1150, Implementing Regu- } \\
\text { lation (EU) No 615/2014, Implementing Regulation (EU) 2015/1368 } \\
\text { and Implementing Regulation (EU) 2017/39 in respect of certain } \\
\text { measures to counter the crisis caused by the COVID-19 pandemic. }\end{array}$ & $\begin{array}{l}\text { Support for producers of fruits and vegetables, } \\
\text { grapes, olive oil and table olives, beekeeping. }\end{array}$ \\
\hline & $\begin{array}{l}\text { Commission Implementing Regulation (EU) } 2020 / 601 \text { of April 30, } \\
2020 \text { on emergency measures derogating from Articles } 62 \text { and } 66 \text { of } \\
\text { Regulation (EU) No } 1308 / 2013 \text { of the European Parliament and of } \\
\text { the Council on the validity of permits for the planting of grapes and } \\
\text { grubbing-up in the event of early transplantation. }\end{array}$ & $\begin{array}{l}\text { This regulation continues: the validity of } \\
\text { permits for planting and transplanting of plants } \\
\text { ending in 2020; eradication period in case of } \\
\text { early transplantation of vineyards. }\end{array}$ \\
\hline
\end{tabular}


(End of Table 1)

\begin{tabular}{|c|c|c|}
\hline \multicolumn{2}{|r|}{ Name of regulation } & Review \\
\hline 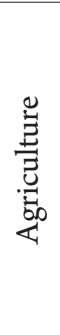 & $\begin{array}{l}\text { Commission Implementing Regulation (EU) } 2020 / 531 \text { of April } \\
\text { 16, 2020, setting a derogation from Article } 75 \text { section 1, third } \\
\text { paragraph of Regulation (EU) No } 1306 / 2013 \text { of the European } \\
\text { Parliament and Council regarding the level of advances for direct } \\
\text { payments and area-related measures, as well as measures related } \\
\text { to animals in the framework of rural development and derogation } \\
\text { from Article } 75 \text { section } 1 . \text { The first paragraph of Article } 2 \text { of this } \\
\text { provision in respect of direct payments. }\end{array}$ & $\begin{array}{l}\text { Establishing the level of advance payments and } \\
\text { payments by Member States identified certain } \\
\text { types of support: Annex I to Regulation (EU) No } \\
\text { 1307/2013; Article } 67 \text { section } 2 \text { of Regulation } \\
\text { (EU) No 1306/2013. }\end{array}$ \\
\hline
\end{tabular}

Source: formed by the authors on the basis of («COVID-19»).

2010; «Pro vnesennia zmin do Zakonu Ukrainy "Pro Derzhavnyi biudzhet Ukrainy na 2020 rik"; «Pro zatverdzhennia Poriadku nadannia ta povernennia koshtiv», 2020; «Pro zatverdzhennia Poriadku nadannia finansovoi derzhavnoi», 2020; «Pro sotsialnu pidtrymku zastrakhovanykh osib», 2020) and European regulations on mitigating the impact of quarantine measures on business, we see the need to improve Ukrainian legal framework in order to support small business in this period, especially agricultural producers, one of the key suppliers of food for the population.

Another problem for small business was the lack of effective public financial support during the pandemic. Some steps to mitigate the impact of quarantine restrictions have been proposed by the state, including reducing the tax burden on small business entities. All these anti-crisis measures implemented by Ukrainian government can be divided into the following types (Table 2).

Organizations and institutions of the European Union also take measures to support small business entities in their member states. Thus, on April 06, 2020, the European Commission opened access to financing of $€ 1$ billion from the European Fund for Strategic Investments to provide guarantees to the European Investment Fund to stimulate local banks and other creditors to provide liquidity to at least 100,000 European small and medium enterprises ( $\ll$ Jobs and economy during the coronavirus pandemic $\gg$ ).

On September 30, 2020 the EIB Group, consisting of the European Investment Fund and the European Investment Bank, agreed with the Commerzbank on a new favourable lending scheme, providing German SMEs with up to $€$ 500 million. On October 06, 2020 the European Investment Fund and Raiffeisenbank signed an agreement on a guarantee of $€ 10$ million to support small and medium-sized private and public enterprises in the field of culture and creativity in Bulgaria ( $\ll$ Jobs and economy during the coronavirus pandemic $\gg)$.

In October, a group from the European Investment Bank agreed to provide $€ 490$ million to Italian leasing specialist Alba Leasing as part of a securitization financing operation, providing access to new financial resources of $€ 1$ billion for small, medium and medium-sized companies in Italy. Also on October 20, 2020 the EIB Group and BancoSantander in Spain agreed on additional financing on favourable terms for Spanish small, medium and medium-sized enterprises affected by the coronavirus crisis ( $\ll$ Jobs and economy during the coronavirus pandemic $\gg$ ).

EU member states have also implemented their own mechanisms to support small businesses. We shall consider some of them. Poland has introduced co-financing of fixed costs for small and medium-sized enterprises (SMEs). Subsidies were provided to companies under the financial shield of the Polish Development Fund in the amount of up to $70 \%$ of fixed costs, not covered by income. The condition will be a reduction in revenues by $30 \%$ compared to the same period in 2019 . The solution will apply to industries that are subject to sanitary restrictions («Kolejny pakiet 10 działań antykryzysowych dla polskich firm»).

In Germany, the government has simplified the possibility of obtaining loans from guarantee banks for small business affected by coronavirus. Small business entities can also receive a subsidy in the event of a decrease in sales related to the pandemic («Informationen für kleine, mittlere und große Unternehmen Einleitung»). France has introduced deferred payment of rent, water, gas and electricity bills for the smallest small business («Lactivité de votre entreprise est impactée par le Coronavirus COVID-19»). 
In Latvia, state and municipal capital companies temporarily exempt entrepreneurs in the sectors affected by the Covid-19 crisis from rent or make decisions on the reduction of rents. To mitigate the effects of the crisis, banks have developed solutions to determine credit holidays and defer the principal amount, as well as to temporarily defer other liabilities («Covid-19 aktualitātes»).

One of the problems for small business is distrust of the proposed mechanisms of state support and misunderstanding (sometimes complete rejection) of the restrictions imposed in Ukraine in order to overcome coronavirus. Small business entities are usually insufficiently informed about the anti-crisis support provided by the government.

As observed from the table given above, Ukraine, in order to reduce the impact of quarantine restrictions on the activities of small business entities, has proposed measures to support them, namely credit, social, tax, information and other types of support. We believe that such steps are insufficient because small business needs additional incentives to stabilize the work during the "pandemic" crisis and they have to be expanded.

\section{Proposals to improve the state support for small business in Ukraine during the pandemic}

First, small business entities can quickly reorient their own production to the output of antiepidemic products and in a short time to provide government agencies with them, including medical and educational institutions. Therefore, the implementation of part of the tender procurement of small and micro enterprises, by fixing the appropriate quota in the legislation, will not only stabilize their activities during the "pandemic crisis", but also will stimulate their further development.

Secondly, the state should take into account the important specifics of many micro-enterprises when establishing quarantine restrictions,

Table 2

\section{Types of state support for small business during the coronavirus disease in Ukraine}

\begin{tabular}{|c|c|}
\hline Type of support & Review \\
\hline Credit benefits & $\begin{array}{l}\text { - Banks are advised to restructure loans to businesses affected by pandemic-related restrictions. } \\
\text { - Under the loan program 5-7-9\%, for the period of quarantine or restrictive measures and within } 90 \text { days } \\
\text { from the date of its (their) cancellation, an anti-crisis support package for MMPs is offered; }\end{array}$ \\
\hline Tax preferences & $\begin{array}{l}\text { - Small business enterprises are exempt from many taxes and fees during the quarantine period (land fees, } \\
\text { real estate tax for residential premises, single social security tax). } \\
\text { - Restriction of fines and moratorium on inspections. } \\
\text { - Permission for individual persons-entrepreneurs not to fill in the income book temporarily. } \\
\text { - Extension of deadline for submission of the annual declaration of property and income until June 30, } \\
2020 \text { inclusive. } \\
\text { - Postponement of the introduction of cash register for all categories of taxpayers under the simplified } \\
\text { system. } \\
\text { - Increasing annual income limits for sole proprietors of } 1,2 \text { and } 3 \text { groups. } \\
\text { - Exemption from VAT when importing goods needed to combat coronavirus. } \\
\text { - Simplification of the accounting system for products and introduction of a zero rate of excise tax for } \\
\text { state-owned enterprises that produce disinfectants based on alcohol. } \\
\text { - Termination of appeals against decisions of regulatory authorities. } \\
\text { - Taking into account the costs of VAT payers on transmission without restrictions, as a contribution to } \\
\text { the fight against coronavirus, health care facilities of medicines, drugs, equipment, etc. } \\
\text { - Granting local governments the right to decide on changes in the rates of the single tax. }\end{array}$ \\
\hline Social support & $\begin{array}{l}\text { - Small and medium-sized business owners who have employees are provided with partial } \\
\text { unemployment benefits. } \\
\text { - One-time assistance in the amount of UAH 8,000 is provided to insured persons and business entities. }\end{array}$ \\
\hline $\begin{array}{l}\text { Agricultural } \\
\text { business support }\end{array}$ & A variety of soft loans and grants are provided to agricultural small businesses. \\
\hline $\begin{array}{l}\text { Information } \\
\text { support }\end{array}$ & Simplified access to public services through a variety of online resources. \\
\hline
\end{tabular}

Source: built by the authors on the basis of ( «Podatkovyi kodeks Ukrainy», 2010; «Pro zatverdzhennia Poriadku nadannia finansovoi derzhavnoi», 2020; «Pro sotsialnu pidtrymku zastrakhovanykh osib», 2020; «Portal dlia pidpryiemtsiv»; «Prohramy pidtrymky biznesu»; «Dostupni kredyty 5-7-9\%») 
especially agricultural entities and their need for markets (subject to compliance with relevant antiepidemic sanitary norms) as the main, only places for them to sell products, goods or services.

Third, the state can develop mechanisms to reimburse the costs incurred by small business for the purchase of anti-epidemic means of protection (masks, antiseptics). It is necessary to provide an opportunity for small business to apply to a designated government agency and receive compensation from the budget spent funds.

Fourth, many small business enterprises, when operating in rented buildings and facilities, need to be reimbursed for these costs. Most European Union countries have made it possible for their small business to reimburse the costs of renting premises, subject to pandemic restrictions. Ukraine can introduce a similar support measure for its business.

Fifth, it is possible to introduce additional subventions from the state to local budgets in order to compensate their loss of revenue from the reduction of tax rates, which was introduced to support small business. This can encourage local governments to reduce relevant taxes and fees.

Due to the restrictions imposed by the government, it can be noted that small business entities need the increased support from the state during the "pandemic crisis" to address the problems that have arisen in connection with the new situation.

\section{Conclusions}

Based on the analysis of the impact of coronavirus disease on small business in Ukraine, the following conclusions can be drawn:

1. Due to the introduction of quarantine restrictions by the government to counter the spread of coronavirus, small business entities have faced the following problems: limitation or cessation of activities in connection with the implemented quarantine measures; reduction of financial resources; forced transition to remote work; incurring additional costs for anti-epidemic drugs; lack of state support, etc.

2. The analysis of formation of Ukrainian and European regulatory framework concerning the mitigation of influence of the entered quarantine restrictions on activity of the enterprises is carried out, and also directions for improving the national legislation on this problem are offered.

3. Ukraine and European countries are implementing customs, credit, social, tax, information and other types of mitigation measures to support small businesses affected by the spread of coronavirus disease (COVID-19).

4. In order to improve the economic situation of small business, it is proposed to take the following steps for the period of quarantine and after the end of restrictions: to provide a quota for public procurement in small businesses; not to prohibit the functioning of markets, provided that they comply with anti-epidemic sanitary norms; reimbursement of expenses incurred for the purchase of anti-epidemic means of protection; to introduce additional subventions from the state to local budgets; compensation for the cost of renting premises, etc.

Consequently, the impact of the spread of coronavirus disease on small business in Ukraine and the EU is significant, which requires the state and local governments to develop and implement measures to systematically support small business entities in order to stabilize the economic situation, prevent a deep economic crisis and ensure future reserves for the further development of business in Ukraine and EU countries.

\section{References:}

COVID-19. Access to European Union law. Available at: https://eur-lex.europa.eu/content/news/ index.html

Jonathan Dimson, Zdravko Mladenov, Ruchi Sharma, Karim Tadjeddine (2020). COVID-19 and European small and medium-size enterprises: How they are weathering the storm. Available at: https://www.mckinsey.com/industries/public-and-social-sector/our-insights/covid-19-and-europeansmall-and-medium-size-enterprises-how-they-are-weathering-the-storm

Kodeks zakoniv pro pratsiu Ukrainy. № 322-VIII (1971). Available at: https://zakon.rada.gov.ua/laws/ show/322-08\#Text

Kozhen piatyi malyi biznes mozhe zakrytysia cherez karantyn - opytuvannia EBA. Ofitsiinyi sait Yevropeiskoi Biznes Asotsiatsii (2020). Available at: https://eba.com.ua/kozhen-p-yatyj-malyj-biznesmozhe-zakrytysya-cherez-karantyn-opytuvannya-eva/ 
Official government portal of Ukraine. Dostupni kredyty 5-7-9\%. Derzhavna prohrama. Available at: https://5-7-9.gov.ua

Official government portal of Ukraine. Portal dlia pidpryiemtsiv. Available at: https://sme.gov.ua/ covid19-qa/\#qa2

Official government portal of Ukraine. Prohramy pidtrymky biznesu. Available at: https://covid19.gov.ua/prohramy-pidtrymky-biznesu

Official information website about COVID-19 of the Government of Latvia. Covid-19 aktualitātes. Available at: https://covid19.gov.lv/atbalsts-sabiedribai/ekonomika/uznemejiem/atbalsts-uznemejiem Official site of the Federal Ministry of Economy and Energy of Germany. Informationen für kleine, mittlere und große Unternehmen Einleitung. Available at: https://www.bmwi.de/Redaktion/DE/Coronavirus/ kleine-mittlere-grosse-unternehmen.html

Official site of the Ministry of Finance and Economy of France. Lactivité de votre entreprise est impactée par le Coronavirus COVID-19. Available at: https://www.economie.gouv.fr/files/files/PDF/2020/ Coronavirus-MINEFI-10032020.pdf

Podatkovyi kodeks Ukrainy (2010). № 2755-VI. Available at: https://zakon.rada.gov.ua/laws/ show/2755-17\#n16191

Pro sotsialnu pidtrymku zastrakhovanykh osib ta subiektiv hospodariuvannia na period zdiisnennia obmezhuvalnykh protyepidemichnykh zakhodiv, zaprovadzhenykh z metoiu zapobihannia poshyrenniu na terytorii Ukrainy hostroi respiratornoi khvoroby COVID-19, спричиненої коронавірусом SARS-CoV-2 (2020). № 1071-IX. Available at: https://zakon.rada.gov.ua/laws/show/1071-20\#Text

Pro vnesennia zmin do deiakykh zakonodavchykh aktiv Ukrainy, spriamovanykh na zabezpechennia dodatkovykh sotsialnykh ta ekonomichnykh harantii u zviazku z poshyrenniam koronavirusnoi khvoroby (COVID-19) (2020). № 540-IX. Available at: https:// zakon.rada.gov.ua/laws/show/540-20\#Text

Pro vnesennia zmin do Zakonu Ukrainy "Pro Derzhavnyi biudzhet Ukrainy na 2020 rik" (2020). № 553-IX. Available at: https://zakon.rada.gov.ua/laws/show/553-IX\#Text

Pro zatverdzhennia Poriadku nadannia finansovoi derzhavnoi pidtrymky subiektam mikropidpryiemnytstva ta maloho pidpryiemnytstva (2020) № 28. Available at: https://zakon.rada.gov.ua/ laws/show/28-2020-п\#Text

Pro zatverdzhennia Poriadku nadannia ta povernennia koshtiv, spriamovanykh na finansuvannia dopomohy po chastkovomu bezrobittiu na period karantynu, vstanovlenoho Kabinetom Ministriv Ukrainy $\mathrm{z}$ metoiu zapobihannia poshyrenniu na terytorii Ukrainy hostroi respiratornoi khvoroby COVID-19, sprychynenoi koronavirusom SARS-CoV-2 (2020). № 306 . Available at: https://zakon.rada.gov.ua/laws/show/306-2020-п\#Text

Service website of the Republic of Poland. Kolejny pakiet 10 działan antykryzysowych dla polskich firm. Available at: https://www.gov.pl/web/koronawirus/kolejny-pakiet-10-dzialan-antykryzysowych-dlapolskich-firm

Website of the European Commission. Jobs and economy during the coronavirus pandemic. Available at: https://ec.europa.eu/info/live-work-travel-eu/coronavirus-response/jobs-and-economyduring-coronavirus-pandemic_en 